\title{
ERRATUM
}

\section{Local gene therapy with indoleamine 2,3-dioxygenase protects against development of transplant vasculopathy in chronic kidney transplant dysfunction}

D Vavrincova-Yaghi, LE Deelman, H van Goor, MA Seelen, P Vavrinec, IP Kema, P Gomolcak, A Benigni, RH Henning and M Sandovici

Correction to: Gene Therapy (2016) 23, 797-806; doi:10.1038/ gt.2016.59; published online 4 August 2016
Following the online publication of this article, noted that the article title contained errors. The complete and correct title appears above. 